
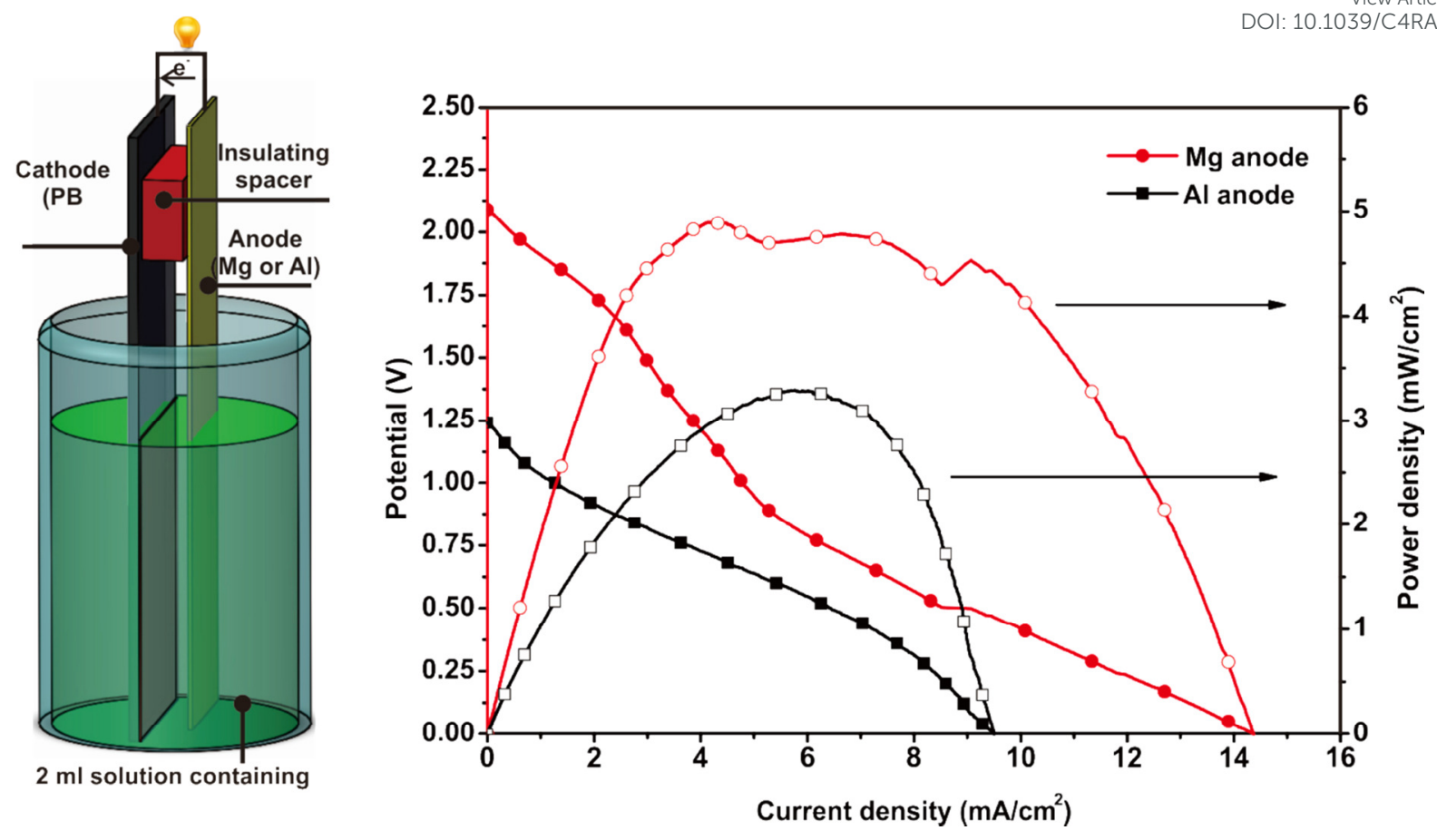

A one-compartment hydrogen peroxide semi-fuel cell was fabricated using a metallic anode (Mg or Al) and Prussian blue as the cathode to improve the power density of the device. 


\title{
COMMUNICATION
}

\section{Membraneless Hydrogen Peroxide Micro Semi-Fuel Cell for Portable Applications $\uparrow$}

Cite this: DOI: $10.1039 / \times 0 \times x 00000 x$

\author{
Seyed Ali Mousavi Shaegh, ${ }^{a+}$ Seyyed Mohsen Mousavi Ehteshami ${ }^{b, c^{+}}$Siew Hwa \\ Chan, ${ }^{b, c^{*}}$ Nam-Trung Nguyen ${ }^{d}$ and Swee Ngin Tan ${ }^{e}$
}

Received 00th January 20xx,

Accepted 00th January 20xx

DOI: $10.1039 / x 0 \times x 00000 x$

www.rsc.org/

\begin{abstract}
This communication describes the first one-compartment hydrogen peroxide semi-fuel cell as a micro-power source for miniaturized applications. This power source is inspired by taking advantage of the high energy content of metals and design flexibility, light weight and ease of packaging. Benefiting from oxidation of metals, including magnesium $(\mathrm{Mg})$ or aluminium $(\mathrm{Al})$, at the anode and reduction of hydrogen peroxide $\left(\mathrm{H}_{2} \mathrm{O}_{2}\right)$ at the cathode, theoretical specific energies of $8600 \mathrm{Wh} \mathrm{kg}^{-1}$ and $17000 \mathrm{Wh} \mathrm{kg}^{-1}$ are achievable. Fabricating a cell with $\mathrm{Mg}$ as the anode and Prussian blue (PB) as the cathode, an open-circuit potential of $2.3 \mathrm{~V}$ with the net maximum power density of $7.5 \mathrm{~mW} \mathrm{~cm}{ }^{-2}$ were achieved. These results are the highest ever reported for one-compartment $\mathrm{H}_{2} \mathrm{O}_{2}$-based power source. This cell design can provide a platform for fabrication of a new generation of power sources for portable and miniaturized applications.
\end{abstract}

Portable microelectronic devices including cyborg insects ${ }^{1}$, insectscale robots $^{2}$ and medical point-of-care diagnostic sensors ${ }^{3}$, require micropower sources for autonomous missions and operations. Practically, such micropower sources should have a light weight and a high energy density.

Micro fuel cells have been investigated as micropower sources for portable applications. ${ }^{4,5}$ But few issues still remain to be addressed. First, two reagents representing fuel and oxidant must be introduced to anode and cathode compartments, separately. This generally imposes the need of ancillary components adding complexity for the design. Second, a membrane should be sandwiched between electrodes to provide charge transport between them. Such a membrane-electrode-assembly (MEA) increases the total weight of a micro fuel cell and adds complexity to miniaturization and packaging.

In order to address the above mentioned issues, membraneless micro fuel cells, in various configurations, have been investigated. Membraneless microfluidic fuel cells ${ }^{6,7}$ usually exploit co-laminar flows containing liquid fuel and oxidant reagents in a micro channel. Fuel-oxidant interface represents a virtual membrane to keep reagents separated. Power densities of up to tens of $\mathrm{mW} \mathrm{cm}$ can be reached. But, generally, microfluidic fuel cells need continuous pumping of two streams into the microchannel to provide a confined liquid-liquid interface to avoid fuel crossover. This characteristic results in a reduced net power generation and prevents the deployment of the fuel cell in practical applications.

Ideally, membraneless fuel cells with selective electrodes should provide a prospect to implement anode and cathode in a single compartment. Such a configuration may facilitate delivery of reactants to the electrodes with less required power. Tominaka et al. 8-10 introduced a one-compartment membraneless microfuel cell with a selective electrocatalyst for oxygen reduction in an air-breathing cathode. Each fuel cell was able to use methanol, ethanol or 2propanol containing a supporting electrolyte in a reservoir fabricated in silicon or bendable polymeric substrates. Using full passive delivery of fuel and oxidant, a net power of $10 \mu \mathrm{W}$ was achieved.

Furthermore, an ideal design of a memraneless microfuel cell should exploit only one reactant as both fuel (electron donor) and oxidant (electron acceptor) in a single-compartment design. This feature facilitates fabrication of very compact fuel cells. Hydrogen peroxide has a unique characteristic, usually considered as a carbon-free energy carrier ${ }^{11}$, which can be exploited as both fuel and oxidant in a membraneless one-compartment fuel cell. Hydrogen peroxide benefits from easy transport and handling in aqueous phase. ${ }^{12}$

Yamazaki et al. ${ }^{13}$ used hydrogen peroxide as both electron donor and electron acceptor in an alkaline one-compartment fuel cell. A maximum OCP of $0.13 \mathrm{~V}$ was achieved using $\mathrm{Au}, \mathrm{Ni}, \mathrm{Pt}$ and $\mathrm{Pd}$ wires as a selective anode and an $\mathrm{Ag}$ wire as a selective cathode.

Running a direct hydrogen peroxide fuel cell in acidic conditions is more desirable for hydrogen peroxide-based energy production and storage. ${ }^{14}$ Hydrogen peroxide can be formed under acidic environment via the two-electron reduction of oxygen using solar 
power. ${ }^{11}$ In addition, $\mathrm{H}_{2} \mathrm{O}_{2}$ is more stable in an acidic environment with a lower decomposition kinetics which increases the utilization efficiency of $\mathrm{H}_{2} \mathrm{O}_{2} \cdot{ }^{15}$.

Yamada et al. ${ }^{16}$ fabricated a direct acidic membraneless fuel cell running only on hydrogen peroxide. An OCP of $0.5 \mathrm{~V}$ with a

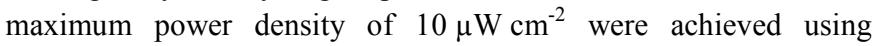
$[\mathrm{Fe} I \mathrm{II}(\mathrm{Pc}) \mathrm{Cl}]$ as a cathode material and a $\mathrm{Ni}$ mesh as anode. Both electrodes were immersed in a reservoir containing an acetate buffer with $0.3 \mathrm{M} \mathrm{H}_{2} \mathrm{O}_{2}$ at a $\mathrm{pH}$ of 3 . Recently, we improved the OCP and maximum power density to $0.6 \mathrm{~V}$ and $1.55 \mathrm{~mW} \mathrm{~cm}^{-2}$ using, ferric ferrocyanide $\left(\mathrm{Fe}_{4}{ }^{\mathrm{III}}\left[\mathrm{Fe}^{\mathrm{II}}(\mathrm{CN})_{6}\right]_{3}\right)$, coated on a carbon-fibre-paper as a cathode material and a $\mathrm{Ni}$ mesh as anode. A $0.5 \mathrm{M} \mathrm{H}_{2} \mathrm{O}_{2}$ solution containing $0.1 \mathrm{M} \mathrm{HCl}$ was used as both fuel and oxidant. ${ }^{14}$ More recently, Yamada et al. used other cyanide complexes coated on carbon cloth as cathode materials and a Ni mesh as anode, and achieved an OCP of $0.78 \mathrm{~V}$ and a maximum power density of $1.2 \mathrm{~mW} \mathrm{~cm}^{-2} .^{17}$

It is very appealing to improve the performance of one-compartment fuel cell for microelectronic portable applications. In this communication, we report a small scale single-compartment semifuel cell using $\mathrm{H}_{2} \mathrm{O}_{2}$ in acidic condition with improved power output compared to other membraneless hydrogen peroxide fuel cells ever reported. The cathode was comprised of Prussian blue coated on carbon-fibre-based paper. ${ }^{14}$ The anode was made of $\mathrm{Al}$ or Mg plates. Both anode and cathode were immersed in a reservoir containing $0.5 \mathrm{M} \mathrm{H}_{2} \mathrm{O}_{2}$ with a supporting electrolyte of $0.1 \mathrm{M} \mathrm{HCl}$, shown in Fig 1. Procedure of $\mathrm{PB}$ synthesis was adopted from elsewhere. ${ }^{18} \mathrm{~PB}$ was coated on carbon-fiber-paper by spraying a solution of $\mathrm{PB}$ containing Nafion ${ }^{\circledR} .^{14}$ Both $\mathrm{Mg}$ and $\mathrm{Al}$ plates had a thickness of $0.25 \mathrm{~mm}$ purchased from Alfa-Aesar and Good Fellow, respectively. A gap between the electrodes was maintained by a silicon rubber slab as an insulating spacer with a thickness of $c a .1 \mathrm{~mm}$.

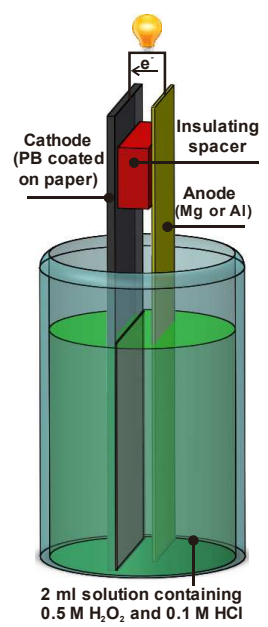

Fig 1 Schematic of the $2 \mathrm{~mL}$ one-compartment semi-fuel cell running on $\mathrm{H}_{2} \mathrm{O}_{2}$ with a supporting electrolyte of $0.1 \mathrm{M} \mathrm{HCl}$. The anode consists of either a $\mathrm{Mg}$ or a $\mathrm{Al}$ plate. The cathode is made of Prussian blue coated on carbon paper.

The overall redox reactions happening in $\mathrm{Mg}-\mathrm{PB}$ and $\mathrm{Al}-\mathrm{PB}$ cells are $4.15 \mathrm{~V}$ and $3.43 \mathrm{~V}$ as presented below in reactions (1) and (2), respectively (See ESI† for more details).
$\mathrm{Mg}+\mathrm{H}_{2} \mathrm{O}_{2}+2 \mathrm{H}^{+} \rightarrow \mathrm{Mg}^{2+}+2 \mathrm{H}_{2} \mathrm{O} ; \mathrm{E}^{0}=4.15 \mathrm{~V}$ vs. SHE
$\mathrm{Al}+\mathrm{H}_{2} \mathrm{O}_{2}+2 \mathrm{H}^{+} \rightarrow \mathrm{Al}^{3+}+2 \mathrm{H}_{2} \mathrm{O}+e^{-} ; \mathrm{E}^{0}=3.43 \mathrm{~V}$ vs. SHE

Hydrogen peroxide has a specific energy of $478 \mathrm{Wh} \mathrm{kg}^{-1}{ }^{19}$ while $\mathrm{Mg}-\mathrm{H}_{2} \mathrm{O}_{2}$ and $\mathrm{Al}-\mathrm{H}_{2} \mathrm{O}_{2}$ cells have specific energies of $8600 \mathrm{Wh} \mathrm{kg}^{-1}$ and $17000 \mathrm{Wh} \mathrm{kg}^{-1}$. For comparison, lithium-ion batteries and lithium-air batteries have theoretical specific energy of less than $1000 \mathrm{Wh} \mathrm{kg}^{-1}$ and $12000 \mathrm{Wh} \mathrm{kg}^{-1} .^{20}$

OCP of two cells was monitored for 600 seconds before running other experiments. $\mathrm{Mg}$-PB cell produced an OCP of $c a .2 .3 \mathrm{~V}$ while OCP of Al-PB cell was $c a$. $1.25 \mathrm{~V}$ (see Fig S1 at ESI $\dagger$ ). Both values are higher than the theoretical OCP of a membraneless hydrogen peroxide fuel cell $(1.09 \mathrm{~V})$. The actual cell open-circuit potentials are lower compared to the theoretical ones. This is attributed to the occurrence of parasitic reactions in the cell causing a significant drop in the cell potential.

Linear potential sweep voltammetry experiment was carried out to study the potential-current characteristics of the device using only $2 \mathrm{ml}$ solution in a $13 \mathrm{~mm}$-diameter container. As shown in Fig 2, a maximum power density of $c a .4 .9 \mathrm{~mW} \mathrm{~cm}^{-2}$ at potential of $1.1 \mathrm{~V}$ was achieved using $\mathrm{Mg}$ plate as the anode and $\mathrm{PB}$ as the cathode. The device using Al as anode material with $\mathrm{PB}$ cathode produced a maximum power density of $3.3 \mathrm{~mW} \mathrm{~cm}^{-2}$ at $c a .0 .58 \mathrm{~V}$. These power densities are three and two times higher, respectively, than that produced by a membraneless hydrogen peroxide fuel cell using Nickel mesh anode and PB-based cathode immersed in a $50 \mathrm{ml}$ solution $\left(1.55 \mathrm{~mW} \mathrm{~cm}^{-2}\right)^{14}$. For $\mathrm{Mg}$ anode with $\mathrm{PB}$ cathode immersed in a beaker including $50 \mathrm{ml}$ solution, a maximum power density of up to $7.5 \mathrm{~mW} \mathrm{~cm}^{-2}$ was achieved. Higher power output is mainly because of improved mass transport to the electrodes.

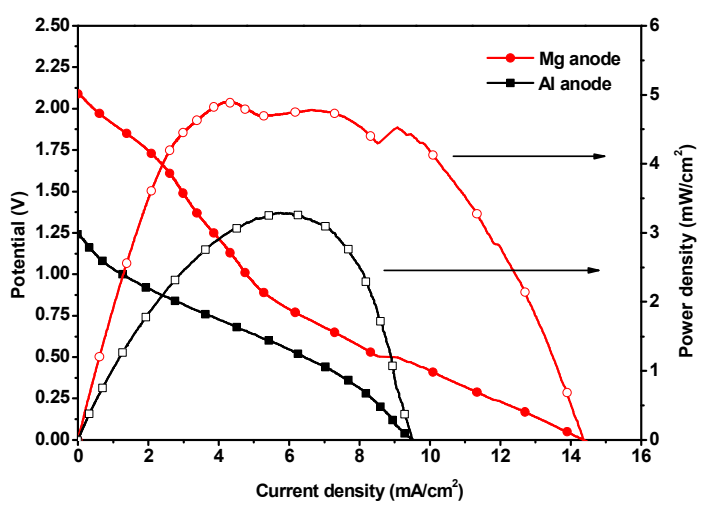

Fig 2 Current-potential and current-power curves of the single-compartment $\mathrm{H}_{2} \mathrm{O}_{2}$ fuel cell/battery with $\mathrm{Mg}$ and $\mathrm{Al}$ plain plate anodes and $\mathrm{PB}$ coated on carbon paper as a cathode. Performance tests were carried out under acidic conditions using $2 \mathrm{~mL}$ solution containing $0.1 \mathrm{M} \mathrm{HCl}$ and $0.5 \mathrm{M} \mathrm{H}_{2} \mathrm{O}_{2}$.

In order to investigate the long term performance and stability of the device, chronoamperometry test was carried out for both cells using $\mathrm{Mg}$ and $\mathrm{Al}$ anodes. As shown in Fig 3, cell with $\mathrm{Mg}$ anode showed a sharp drop in current density compared with the cell with Al anode. The overall decrease of current density for both cells might be attributed to $\mathrm{H}_{2} \mathrm{O}_{2}$ consumption, degradation of electrode electrochemical activity and losses due to mass transfer. In the case 
of the $\mathrm{Mg}$ anode, it was observed that a large area of the electrode was covered by bubbles, limiting $\mathrm{H}_{2} \mathrm{O}_{2}$ transport to electro-catalytic active sites. The source of the bubbles could be either hydrogen or oxygen molecules produced from metal corrosion or hydrogen peroxide decomposition (see ESI for corresponding chemical reactions $\dagger$ ).

To investigate the prevailing mechanism responsible for the degradation of performance of the cell with $\mathrm{Al}$ as anode, the solution in the reservoir was changed with a fresh solution, after the first experiment. It was observed that the subsequent current generation followed the same trend of the first operation (see ESI $\dagger$ for experimental results). This implies that the cell performance degradation is mainly attributed to mass transfer which is the result of a combination of bubble formation around anode and $\mathrm{H}_{2} \mathrm{O}_{2}$ consumption.

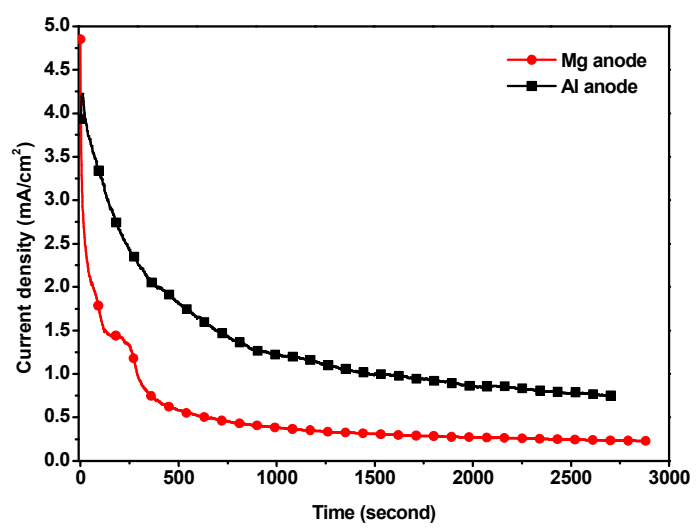

Fig 3 Chronoamperometry curves measured at $1 \mathrm{~V}$ and $0.5 \mathrm{~V}$ for singlecompartment $\mathrm{H}_{2} \mathrm{O}_{2}$ semi-fuel cells with $\mathrm{Mg}$ and $\mathrm{Al}$ anodes, respectively and PB coated on carbon paper as the cathode. Performance tests were carried out under acidic conditions using $0.1 \mathrm{M} \mathrm{HCl}$ and $0.5 \mathrm{M} \mathrm{H}_{2} \mathrm{O}_{2}$.

\section{Conclusion}

Miniaturized one-compartment membraneless $\mathrm{H}_{2} \mathrm{O}_{2}$ semi-fuel cells using magnesium and aluminium as anode materials and Prussian blue as cathode material with high performance were realized. Opencircuit potential and maximum power density were improved considerably compared to the previous one-compartment membraneless $\mathrm{H}_{2} \mathrm{O}_{2}$ fuel cells reported in the literature.

Since the membrane is removed from the structure of the device, there is no requirement for a tight membrane-electrode assembly with passive delivery of reagents to electrodes. In addition, this design benefits from an ease of operation with potential of fuel recirculation to improve performance. These features result in reduced mass of inactive materials and a light-weight assembly and packaging structure, ideal for portable applications. High specific energies with high theoretical OCPs, make $\mathrm{H}_{2} \mathrm{O}_{2}$ semi-fuel cells very appealing for further developments.

The performance of the fabricated device was mainly restricted by a combination of electrochemical kinetics and mass transport. More investigations should be focused on cell chemistry to determine parasitic reactions deviating the cell potential from theoretical values see ESI $\dagger$ ). Synthesised nano-electrocatalysts with three-dimensional structure can be explored in preference to plain metallic thin plates in order to enhance electrocatalytic reactions. In addition, microfabrication techniques can be adopted for making the miniaturized electrodes, reservoir and assembly.

\section{Notes and references}

${ }^{a}$ Singapore Institute of Manufacturing Technology, Singapore 638075, Singapore.

${ }^{b}$ School of Mechanical and Aerospace Engineering, Nanyang Technological University, 50 Nanyang Avenue, Singapore 639798, Singapore.

${ }^{c}$ Energy Research Institute at NTU (ERI@N), Singapore 637553, Singapore.

${ }^{d}$ Queensland Micro- and Nanotechnology Centre, Griffith University, Brisbane 4111, | Australia

$e$ Natural Sciences and Science Education Academic Group, Nanyang Technological University, 1 Nanyang Walk, Singapore 637616

+ These authors contributed equally to this work.

*corresponding author: mshchan@ntu.edu.sg

$\dagger$ Electronic Supplementary Information (ESI) available: [details of any supplementary information available should be included here]. See DOI: $10.1039 / \mathrm{c} 000000 \mathrm{x} /$

1. H. Sato, C. W. Berry, Y. Peeri, E. Baghoomian, B. E. Casey, G. Lavella, J. M. VandenBrooks, J. Harrison and M. M. Maharbiz, Frontiers in Integrative Neuroscience, 2010, 3.

2. K. Y. Ma, P. Chirarattananon, S. B. Fuller and R. J. Wood, SCIENCE, 2013, 340, 603-607.

3. P. Yager, T. Edwards, E. Fu, K. Helton, K. Nelson, M. R. Tam and B. H. Weigl, Nature, 2006, 442, 412-418.

4. N. T. Nguyen, Chan, S.H. , Journal of Micromechanics and Microengineering 2006, 16, R1-R12

5. C. K. Dyer, Journal of Power Sources, 2002, 106, 31-34.

6. E. Kjeang, Djilali,N., Sinton, D., Journal of Power Sources, 2008.

7. S. A. Mousavi Shaegh, Nguyen, N.T., Chan, S.H., International Journal of Hydrogen Energy, 2011, 36, 5675-5694.

8. S. Tominaka, Ohta, S., Obata, H.Momma, T., Osaka, T., Journal of the American Chemical Society, 2008, 130, 10456-10457.

9. S. Tominaka, H. Nishizeko, S. Ohta and T. Osaka, Energy Environ. Sci., 2009, 2, 849-852.

10. S. Tominaka, H. Nishizeko, J. Mizuno and T. Osaka, Energy Environ. Sci., 2009, 2, 1074-1077.

11. Y. Yamada, Y. Fukunishi, S.-i. Yamazaki and S. Fukuzumi, Chemical Communications, 2010, 46, 7334-7336.

12. D. Robert S, International Journal of Hydrogen Energy, 2010, 35, 1049-1053.

13. S.-i. Yamazaki, Z. Siroma, H. Senoh, T. Ioroi, N. Fujiwara and K. Yasuda, Journal of Power Sources, 2008, 178, 20-25.

14. S. A. Mousavi Shaegh, N.-T. Nguyen, S. M. Mousavi Ehteshami and S. H. Chan, Energy Environ. Sci., 2012, 5, 8225-8228.

15. X. Jing, D. X. Cao, Y. Liu, G. L. Wang, J. L. Yin, Q. Wen and Y. Y. Gao, Journal of Electroanalytical Chemistry, 2011, 658, 4651.

16. Y. Yamada, S. Yoshida, T. Honda and S. Fukuzumi, Energy Environ. Sci., 2011, 4, 2822-2825.

17. Y. Yamada, M. Yoneda and S. Fukuzumi, Chemistry - A European Journal, 2013, 19, 11733-11741.

18. G. Selvarani, S. K. Prashant, A. K. Sahu, P. Sridhar, S. Pitchumani and A. K. Shukla, Journal of Power Sources, 2008, 178, 8691.

19. A. E. Sanli and A. Aytac, International Journal of Hydrogen Energy, 2011, 36, 869-875.

20. B. Scrosati and J. Garche, Journal of Power Sources, 2010, 195, 2419-2430. 
